Opinion Section

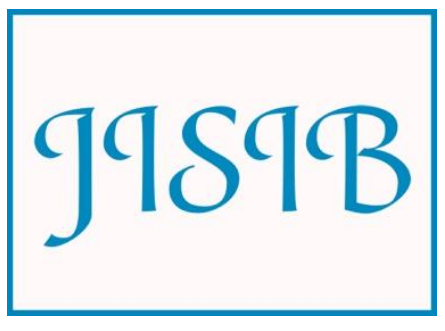

Available for free online at https://ojs.hh.se/

Journal of Intelligence Studies in Business Vol 4, No 1 (2014) 43-57

\title{
Contribution to reduce risks related to strategic decisions in new uncertain competitive environments: The case of Algerian State-Owned Firms
}

\author{
Abdelkader BAAZIZ ${ }^{1}$ and Luc QUONIAM ${ }^{2}$ \\ ${ }^{1}$ IRSIC Laboratory, Aix-Marseille University, France \\ ${ }^{2}$ University of Sud Toulon Var, France \\ Email: kbaaziz@gmail.com, mail@quoniam.info,
}

Received May 7, accepted May 20, 2014

\begin{abstract}
The aim of this paper is to show the complexity of the political, legal, social and economic environments where the Algerian State-Owned Firms operate. These environments are qualified by "uncertainty" given the instability of the different parameters cited. Since 1988, Algeria has initiated deeper economic reforms supported by significant legislation and international agreements. In this uncertain environment, Algerian State-Owned Firm cannot rely only on their internal capabilities. They should, create partnerships, both with suppliers, subcontractors, universities and even competitors. There is a need for these firms to: Transform their organization to a new form improved for unexpected events and enough resilience to adapt to uncertain environments. Build a Strategic Intelligence Information System able to facilitate decisionmaking and reduce risks inherent to the strategic choices. Find ways to reverse choice when unexpected events occur. This article shows there is a need to handle the following risks: Inertia against the process of organizational transformation, wrong understanding of the received signals from the environment and poor reaction of the decision-maker to signals and events in the environment.
\end{abstract}

KEYWORDS: Strategic Intelligence Information System; Knowledge Management, Competitive Intelligence; Business Intelligence; Decision-making under Uncertainty, Risk 


\section{Opinion Section}

\section{Introduction}

Since 1988, Algeria has initiated deeper economic reforms guided by two famous international agreements:

- Signature on December 2001, the Association Agreement with the European Union, effective since September 2005; ${ }^{(1)}$

- Application for membership to the WTO introduced on June 1987, considered by the Algerian government as "a sovereign choice and necessity". (2) Negotiations are still ongoing in 2014.

These reforms are supported by a significant legislation. The most important are ${ }^{(3)}$ :

- Law 90-10 of April 14, 1990 on the money and credit, amended by Ordinance 03-11 of August 26, 2003 on money and credit;

- The Investment Code promulgated on October 13,1993 , completed by Ordinance $01-03$ of August 20, 2001 on the development of investment and amended by Ordinance No. 0608 of 15 July 2006 ;

- Ordinance 01-04 of August 20, 2001 on the organization, management and privatization of state-owned enterprises;

- Law 10-05 of August 15, 2010 on the Competition, amending and completing Ordinance 03-03 of July 19, 2003 and Law 0812 of June 25, 2008;

- Law 13-01 of February 20, 2013 on the Hydrocarbons, amending Law 05-07 of April 28, 2005 and Ordinance 06-10 of July 29, 2006;

- Various finance laws until 2014.

It has resulted in an open economic market affecting almost all sectors in favor of new private and foreign entrants. This opening has not spared even some sectors considered strategic and largely protected until the end of the 1990s, such as Mining and Energy (Baaziz, 2004).

( $\left.{ }^{1}\right)$ Official website of European Union, «UE, Instrument européen de voisinage et de partenariat - Algérie Document de Stratégie», 2007-2013, Available at: http://ec.europa.eu/external_relations/algeria/index en.htm

( $\left.{ }^{2}\right)$ Official website of Ministry of Foreign Affairs. Available at: http://www.mae.dz

$\left(^{3}\right)$ Official wesite of Ministry of Industry, PME and Promotion of Investments. Available at: http://www.mipmepi.gov.dz
Among the first effects of these reforms, we've observe deeper changes in the Algerian economic landscape, including (Baaziz, 2004):

- Reorganization of State-Owner's Firms called "Economic Public Enterprises" to "Corporations Enterprises" or "Limited Liability Companies";

- Bankruptcy or privatization of hundreds of State-Owned Enterprises ${ }^{(4)}$;

- Set up of many partnerships (such as joint venture, merger, acquisition, association and interest group) with foreign firms in various sectors such as consumer electronics, chemical and pharmaceutical industry and even the energy sector;

- Market/customer orientation and new marketing practices.

Inapt to follow quick changes and uncertainty of the new environments, Algerian State-Owned Firms are strongly shaken by deregulation of their market usually protected and acquired (Baaziz, 2012). They find themselves in an aggressive competitive environment occupied by new emergent entrants.

The Algerian government has abandoned its protector role without providing a required regulatory role. In fact, the transition from a planned economy based on state monopole on all economics sectors to a market economy based on free competition and characterized by the emergence of local and foreign private sector implies radical changes both politically and institutionally (regarding Algerian State) on the organizational, strategic and technological plans for State-Owned Firms.

The classic business model within which the Algerian State-Owned Firms was not confronted to market adaptation needs. The management approach was purely rules-based forecasting, planning and rationalization of tasks without unduly concern with the market itself. Henri Fayol in the 1920's, described the five principles of this style of management still relevant in almost all Algerian State-Owned Firms delaying the leap of change: planning, organizing, commanding, coordinating, controlling (Fernandez, 2008).

( $\left.{ }^{4}\right)$ Official wesite of Ministry of Industry, PME and Promotion of Investments. Available: http://www.mipmepi.gov.dz 


\section{Opinion Section}

\section{Method}

What organizational and technological leverages will grasp Algerian State-Owned Firms to deal with the uncertainties of this new competitive environment? It is obvious that in such uncertain competitive environment, the Algerian StateOwned Firm cannot rely only on its internal capabilities. It must look out of the box, create partnerships, both with suppliers, contractors, universities and even competitors (Couture, 2000).

On the organizational level, it is necessary to find new forms of organization that are more flexible, resilient and able to promote innovation and hold strategic positioning in such environments (Baaziz \& Quoniam, 2013).

On the technological level, a strategic alignment of an Information System is needed and will be able to (Baaziz, 2012):

- Federate internally, its knowledge and critical skills;

- Scan the environment in order to detect any positive signals to grasp desired strategic positioning;

- Facilitate decision making and reduce its risks under uncertainty.

Hence the need for these firms to:

Transform its current organization to a new form of proactive organization improved for unexpected events and resilient enough to adapt to uncertain environments.

Build a Strategic Intelligence Information System (SIIS), able to facilitate decisionmaking and reduce risks inherent to the strategic choices (Baaziz, 2012).

Find ways to make the reversible choices if occur unexpected events (AO2008, 2012).

\section{What are the risks linked to such changes?}

The risks are closely linked to three (03) sources of uncertainty: (i) Environment; (ii) Information and (iii) Decision-maker.

\subsection{Risks linked to the Environment:}

The major risk in the environment is "inertia" or resistance to fast and radical changes due to the transformation to the new form of organization (Keen, 1981).

\subsection{Risks linked to Information:}

The risk of information is a poor understanding and interpretation of signals received from the environment.

\subsection{Risks linked to the Decision-maker:}

The risk to the Decision-maker is poor reaction to signals and events in the environment.

\section{Literature Review: Environment and Information.}

In the sixth century BC, Sun Tzu in "the art of war", describes how to recognize "a weak signal". For him, an expert should be able to feel (touch, see, hear) what a common man cannot predict, so should be able to feel a weak signal.

Clausewitz (1832) raises the debate about the relationship between war and the economy. Percepts of "military strategy". could be applied to the economic affairs (trade in particular) in this period. Yet, it isn't. It was only in the mid 1960s that it was used by Alfred Chandler in his book "Strategy and Structure" published in 1963, then in 1965 by Igor Ansoff, in his book "Corporate Strategy " (Ducreux et al., 2009).

We often attribute the authorship of "weak signals" to Ansoff. However, as early as 1964, Pierre Massé, "Ponts et Chaussées" Engineer, Plan General Commissioner of the French Republic, in a famous prospective study "Horizon 1985", formulated the concept of " facts promising for the future". This fuzzy concept is paradoxical (because It can be verified only in the future) is considered one of the founders of prospective concepts. In 1967, Massé finished his idea by saying that intuition and reasoning must be confirmed by the facts (Rossel, 2012). Although Ansoff, who has borrowed the idea of weak signal from the theory of information, may be considered to have developed its own parallel approach mainly oriented towards business and management uncertainties, French futurists then treated essentially society and public policy questions (Rossel, 2012).

Bright (1970) had already stated that companies undergoing an increasingly changing and turbulent environment. He was thus one of the first to talk about the importance of environment scanning and monitoring to anticipate technological changes that could give rise to opportunities and threats. He introduced at the same time new concepts such as "signs of change", "significant signal" and "early signals". 


\section{Opinion Section}

On the same assumptions of changing and turbulent environments, Ansoff (1975) developed the concept of "weak signals" as an alternative to "the strategic planning" that in the 1970s and 1980s was a dominant future-oriented approach in firms and organizations. He declared that strategic planning is reasonable in the case of progressive development of historical trends, but it is not operative to deal with the unexpected or surprises. According Ansoff (1975), strategic planning requires strong signals. The information available from the start must be sufficiently precise to enable appropriate responses (Holopainena \& Toivonen, 2012). Ansoff focuses on the responses of the company but also on the related statements of knowledge that is the result of external or internal interactions. According him, the best strategies are divided into three main options: those that improve awareness and understanding of the business, those that increase the flexibility of the company and those that allow the company to directly address threats or opportunities (Rossel, 2012).

Porter (1985) introduced the concept of value chain (internal analysis of the firm with its strengths \& weaknesses) and the concept of the five forces, that all affect the firm (external environment with its opportunities and threats). The combination of the two concepts provides strategic analysis leading to decisions.

Kaplan \& Norton (1992) by formalizing the Balanced Scorecard (BSC) concept through four Perspectives (Financial, Customer, Internal Processes and Growth), built a chain of causes and effects leading to the strategic success of an organization. It based on four assumptions, the first being: "Innovation of creative people is the only insured source of long-term strategic success and every other aspect of the organization can be replicated by others". We understand that it is the knowledge held by the firm.

Cook \& Cook (2000) and Hameed (2004) tried to explain similarities and differences between Knowledge Management (KM) and Business Intelligence (BI).

According to Pesqueux (2004), KM is an area that cannot extend beyond the firm's boundary. As soon as we are interested in what happens outside, we move to another area than Competitive Intelligence (CI). In the strict sense, $\mathrm{KM}$ is the process of internal knowledge creation (knowledge, skills, best practices, etc.), which is not the knowledge obtained from outside, via the Internet, for example. It is rather the "environment scanning". In this case, $\mathrm{CI}$ becomes a requirement for capturing and analyzing signals from the external environment and to deal with its threats and grasp the best opportunities available to the firm.

Jakobiak (2006) tried to explain the link between Knowledge Management and Competitive Intelligence and the contribution of KM to support $\mathrm{CI}$ and its development. According to (Jakobiak, 2006), KM is not a main goal but a simple mean. The assessment of the links between CI and KM provides a large overview of KM techniques grant high interest for CI specialists.

Bretonès \& Said (2006) attempted to analyze the difference and complementarities between two important areas of research: CI and KM, proposing an understanding framework of links between these two areas.

Goria (2006) described the merger, similarities and complementarities between KM and CI domains. The same concerns were raised by (Blondel et al. 2006).

Liebowitz (2006) introduced a concept of Strategic Intelligence (SI). He defines it as the aggregation of other types of intelligentsia able to providing valueadded information and knowledge toward making organizational strategic decisions. The emphasis is on how best to position the firm to deal with future challenges and opportunities to maximize the firm's success. He noted that the SI forms the outer layer of the "onion", with the inside layers being Artificial Intelligence (AI), Knowledge Management (KM), Business Intelligence (BI) and Competitive Intelligence (CI).

\section{Risks and uncertainties.}

Knight (1921) suggests in "Risk, Uncertainty and Profit", the distinction between risk and uncertainty. By expanding the scope of analysis to the general attitude of the actor facing these two concepts, without limited to economic aspects, then we can distinguish three situations:

1. Certainty: Each action is known to lead to certainly, to a specific outcome.

2. Risks: Every action leads to a specific set of possible outcomes and each outcome occurring with a known probability.

3. Uncertainty: The actions may lead to a set of consequences, but where the probabilities of these outcomes are completely unknown. A risky situation where the outcome is unknown to the decision-maker who do not know what 


\section{Opinion Section}

the result will be. This uncertainty can lead to bad choices.

For March \& Shapira (1987), decision making and risk are closely dependent on the context. It is therefore important to look at the context of the decision.

A lot of research on attitudes to risk has informed our understanding of how individuals act to manage risk situations (Baird \& Thomas, 1985) (MacCrimmon \& Wehrung, 1986) (March \& Shapira, 1987) and (Wehrung \& al. 1989).

For Pablo \& al. (1996), once the risky decision is made, the decision maker is likely to focus on how to achieve the best possible result when attempting to take more risks as favorable as possible, inherent in the selected target. This proposal is consistent with organizational research that argues that when firms are against a hostile environment, they act to improve and manage their environment (Pfeffer \& Salancik, 1978).

According to Riabacke (2006), with the exception of studies by (MacCrimmon \& Wehrung, 1986) and (Shapira, 1995), empirical research has not enough focused on the conceptions of risk and risktaking held by managers. Indeed, until now, no study has investigated the manager's risk attitudes in parallel to their actual behavior when handling risky prospects. The area remains relatively open for new research.

For Riabacke (2006), Managers often overlook the normative rules of decision-making in risky situations. They often rely on intuition that seems correct. They justify their inability to handle many situations at risk due to lack of information while affirming their fear of making poor decisions. The majority of managers insist that there are a lot of unwritten rules built into the culture that guide them when making decisions. Using computerbased decision support could be one way to avoid these practices.

Weick \& Sutcliffe (2007) defined five principles for firms to deal with unexpected events and phenomena:

1. Preoccupation with failure: Small failure's hunting is the responsibility of all actors in the firm. Any deviation must be reported as a potential risk.

2. Reluctance to simplify: Everyone must resist to the temptation to simplify.

3. Sensitivity to operations: All levels of the firm must be concerned with its activities and operations.

4. Commitment to resilience: Everyone must ensure the resilience of the system so that operations can continue. Being able to learn from unexpected events to improve the ability to prevent, reduce or even contain future mistakes.

5. Deference to expertise: The decision making process must be fluid, able to reconstruct different situations. The expertise prevails over hierarchical rank.

\section{Organizational transformation...}

The need to make decisions against uncertainty and randomness is a recurring source of risks that can push the firm to cooperate with others. Risk management plays a key role in many strategic decisions (March \& Shapira, 1987).

Most managers spend nearly half their time in planning activities related. But in a complex and changing environment, planning is necessary but not sufficient (Weick \& Sutcliffe, 2007).

We agree the assumption that the alleged strength of organizations is not so obvious (Weick, 2009) and that focusing on the lack of information to decide, managers try to take advantage of uncertain situations. In this perspective, uncertainty and risk are not necessarily a negative impact on firms. They can also create opportunities (Weick, 2009).

Thus organizations should be proactive towards their environment, rather than reactive (Weick, 2009). This shift ("mutation" or "transformation") to a new form of resilient organization is needed to deal with the uncertain environment and support the strategic alignment of its Information System (Baaziz, 2012)

Political, socio-technical and economic aspects are crucial to overcome inertia and begin a transformation process (Besson \& Rowe, 2011).

Transformation process should be achieved through several distinct phases (Besson \& Rowe, 2011). It should be gradual and scalable (Keen, 1981) that firms are very hierarchical, so that they can drive change and overcome the "inertia" inherent in this type of transformation (Besson \& Rowe, 2011). A strategy of change management must be associated to the transformation in order to reduce risks and uncertainties of the mutation's phases (Besson \& Rowe, 2011). 


\section{Opinion Section}

\subsection{Uncertainty in the Decision Making Process}

Decision is a set of processes to select an option among several alternatives. The Decision-maker makes his choice by comparing the expected consequences of different options.

The uncertainty in a competitive environment can come from three different sources: (i) Environment: Context of the environment; (ii) Information: Information captured from the environment; and (iii) Decision-maker: Interpretation of information captured from the environment.

\subsection{Environment uncertainties}

Uncertainties linked to the Environment are variables of environment where the decision is made. The uncertainty factors are either internal or external to the firm.

\subsubsection{Internal factors :}

These are internal factors that influence the decision and act both on upstream and downstream of the decision-making process (AO2008, 2011):

- Information Management: Collection, storage, archiving and inefficient management of information are some probable factors that might disrupt the flow and sharing of the information within a firm. Indeed, few Algerian State-Owned Firms are not yet equipped with an Electronic Document Management (EDM) for the effective management of their important records and documents (Baaziz \& Quoniam, 2013).

- Hierarchical factors: Main characteristic of the hierarchical organization that may have a big impact on the decision readability (Baumard, 1997). Majors proxy manager in Algerian State-Owned Firms, don't know the extent of their delegated powers of decision. To avoid any legal liability resulting from decision making, most of these managers turn to their superiors at the first difficulty they encounter. In this case, the instructions returned by the superiors are usually verbal thereby complicating decision-making process and finally, the legal responsibility falls on the proxy manager.

\subsubsection{External factors:}

These are external contextual factors that may influence the firm's decision and the future of the firm (Baaziz, 2012; AO2008, 2011):

- Shareholder pressure: The corporate management is accountable to its shareholders. This pressure is higher when the exclusive shareholder (the owner) is the State as in case of Algerian State-Owned Firms.

- Power of political lobby: The political cooptation around a power lobby (group effect) implies the main manager's profile is not the managerial competencies but simply that allegiance to the political group is the necessary condition for access to managerial positions in state-owned firms. Therefore, these managers don't have skills and attitudes of decision-makers; they systematically refer to the goodwill of the political lobby. This group effect is in fact a behavior pattern of a person bound to the status requirements and the group's expectations. Political affiliation is often preferred over the sense of belonging to the firm.

- Pressure of social partner (Syndicate): The weight of the social partners is more important in social and professional conflicts in the StateOwned Firms than in the private sector. In fact, the Syndicates are deeply entrenched in the Algerian State-Owned Firm and have a direct impact on major decisions. The pressures are generally focused on salary increases for SONATRACH in the second half of $2011^{(5)}$, and ALGERIE TELECOM in December $2012^{(6)}$, opposition to the privatization of StateOwned Firms and their consequences such as layoff plans result of the strike of workers following the acquisition of all shares of the ENGI by the German giant of Industrial Gas LINDE in July $2011^{(7)}$.

$\left.{ }^{5}\right)$ El-Watan, newspaper of June 09th, 2011, Sonatrach : Malaise sur les salaires, Available: http://www.elwatan.com/economie/sonatrachmalaise-sur-les-salaires-06-09-2011-

138723 111.php

$\left.{ }^{6}\right)$ Liberté, newspaper of December 13th, 2012, Conflit Algérie Télécom, Un conseil syndical prévu avant la fin décembre, Available: http://www.algerie360.com/algerie/conflit-algerietelecom-un-conseil-syndical-prevu-avant-la-findecembre/

$\left(^{7}\right)$ Le Quotidien d'Oran, newspaper July 9th, 2011, Grève des travailleurs de Linde Gas Algérie: Les hôpitaux risquent de manquer d'oxygène. Available: $\quad$ http://www.lequotidienoran.com/index.php?news $=5155366$ 


\section{Opinion Section}

To curb a social climate in effervescence, managers tend to "calm the game", temper their actions and freeze critical decisions. Anyway, in case of deterioration of the social climate (strike threat by the unions "social partner", for example), their hierarchies prefer sacrificing them in order to maintain a precarious equilibrium of social peace. Given this state, managers prefer a status quo leading to inertia.

- Threat of merger and acquisition / privatization: The potential grouping between two firms makes them unstable. This instability is most severe for State-Owned Firms planned for privatization under the Ordinance 01-04 of August 20, 2001 related to the organization, management and privatization of "Public Economic Enterprises" (Baaziz \& Quoniam, 2013). A total of 417 State-Owned Firms were privatized between 2003 and 2007. ${ }^{(8)}$

- Market trends: The pressure of new competitive environment brings much new information unexpected and incomprehensible. While a number of programs are in place to develop the non-petroleum economy, Algeria remains heavily dependent on oil and gas exports, which represent $97 \%$ of total exports and roughly $30 \%$ of GDP. This dependency remains a real barrier to build a sustainable development. According Oxford Business Group report about Algeria: In recent years, stagnating investor interest has raised concerns about Algeria's ability to sustain current production levels, as a number of maturing fields will need to be replaced by new projects in the near term. Following a number of lackluster bidding rounds over the past four years, the government launched a review of Hydrocarbons Law with the view to make the sector more attractive to foreign investors. ${ }^{(9)}$

- Laws \& regulations' changes: Unlike the national and foreign private firms that appeal to the international law firms, the Algerian State-Owned Firms overlook the contents of the Algerian legal arsenal in the continuing changes. (Baaziz \& Quoniam, 2013). For

$\left({ }^{8}\right)$ Official wesite of Ministry of Industry, PME and Promotion of Investments. Available: http://www.mipmepi.gov.dz

$\left.{ }^{9}\right)$ Oxford Business Group, Algérie: Bilan de l'année 2012, January $16^{\text {th }}$, 2013, Available : http://www.oxfordbusinessgroup.com/economic_u pdates/algérie-bilan-de-l'année-2012 example, the hydrocarbon law was amended twice in less than ten years, the first occurred one year after the promulgation of the law. Each year, the promulgation of the Finance Act is systematically followed by a substantial and significant revision. Thus, the supplementary budget law "LFC 2009" was marked by the adoption of the letter of credit as the only mode of payment for foreign trade transactions, with an immediate effective date. This has caused serious disruptions in the

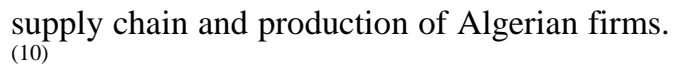

- Criminalization of the wrong management act: Long as the subject was taboo. Decision leading to "bad business results" is not just a "wrong management act" but may be considered as an "economic crime" in light of the Algerian laws. Therefore, no range for error due to the undertaken risk is given to Managers who prefer the status quo to make a decision that dragged him to court or even jail. The Algerian President Abdelaziz Bouteflika has instructed the government to prepare appropriate legislation to decriminalize the management act. ${ }^{(11)}$ The decriminalization of the management act will end the confusion that makes victims among executive's managers. Examples are numerous, we only mention: criminal trial of SIDER executive's managers' in 1997, CNAN case in 2006, SONATRACH case between 2010 to 2013, etc. For Master Zahouane (Lawyer and Human Rights Activist): "We should clear up the confusion between the management act which is the administrative responsibility and criminal act which is the penal responsibility (...) The penalty for the management error must be disciplinal not penal (...) Releasing the management act without being assimilate that to impunity". (12)

- Legal context and partnership: The projects

$\left({ }^{10}\right)$ Le Quotidien d'Oran, newpaper of October 1st, 2009, Pr. Mebtoul A. (Interview with.), Situation du secteur financier algérien et problème du crédit documentaire (credoc). Available: http://www.lequotidien-

oran.com/index.php?news $=5127150$

$\left(^{11}\right)$ El-Moudjahid, newspaper of February $02^{\text {nd }}$, 2011, Selon des avocats : La dépénalisation de l'acte de gestion mettra fin à la "confusion" et libérera l'acte d'entreprendre. Avalaible : http://www.elmoudjahid.com/fr/actualites/9007 $\left(^{12}\right)$ El-Moudjahid, newspaper of February $02^{\text {nd }}$, 2011, op-cited. 


\section{Opinion Section}

developed in partnership with several firms and the contracts concluded between them are liable to influence decisions or to hide information. The conflict between SONATRACH and its partners ANADARKO and MAERSK is an edifying example this situation. The difficulty of interpreting the regulation on Exceptional Profits Taxes (TPE regulation), forced SONATRACH to pay compensation up to $\$ 4.4$ billion for ANADARKO and \$920 million for MEARSK. ${ }^{(13)}$ Nasreddine Lezzar (arbitration expert), says: "Sonatrach erred on two levels; the first being of retiring on the Aventine while the second evoked the choice to allocate the defense of the national company to an U.S. law cabinet (..) Sonatrach, the Algerian state company, was advised, in this case the volume of an affair of State, by an U.S. law cabinet, against an American company the size of a State. I would not presume to question the professionalism of the concerned cabinet, but at this level of interest, we must not allow the shadow of doubt". (14)

\subsection{Information uncertainties}

Uncertainties linked to the Information are proprieties of this information in an environmental context where the decision is made (Zio \& Pedroni, 2012; AO2008, 2011; Zimmermann, 2000; Armacosta \& Pet-Edwards, 1999 and Baumard, 1997):

- No information: lack of information.

- Incompleteness: Partial information due to the incapability to obtain certain information or to a problem at the time of knowledge capitation or to the existence of general information usually true but subjected to exceptions that we

$\left.{ }^{13}\right)$ El Watan, newpaper of March 12th, 2012, Roumadi M., Fin du différend avec Anadarko et Maersk L'Algérie paye cher la gestion opaque de Sonatrach, Available: http://www.elwatan.com/actualite/l-algerie-payecher-la-gestion-opaque-de-sonatrach-12-03-2012162499_109.php http://lequotidienalgerie.org/2012/03/12/lalgeriepaye-cher-la-gestion-opaque-de-sonatrach/ $\left({ }^{14}\right)$ El Watan, newspaper of June 29th, 2013, Elles cumulent les procès à l'international, nos entreprises sont mal gouvernées juridiquement, Available: http://www.elwatan.com/actualite/nosentreprises-sont-mal-gouvernees-juridiquement-2906-2013-219240_109.php http://www.djazairess.com/fr/elwatan/419240 cannot enumerate or predict (BouchonMeunier, 1990).

- Centralization: Excessive centralization of strategic information (Baumard, 1997). It is a common practice in Algerian State-Owned Firms where many documents have confidential status. The information is not simply an intellectual product but a political instrument for lobbies. The replay through the Information Systems affects the interests of particular influential groups.

- Significance: The information is only a tiny part of the decision-making process in the firm (Keen, 1981).

- Ambiguity: All languages have words that have different meanings depending on the context. This linguistic imprecision causes multiple conflicting interpretations, hence confusion and lack of understanding (Thiry, 2002).

- Subjectivity: This may be due to the subjective interpretation of little bits of available information. Depending on their skills and cultures, different analysts may provide different interpretations or even contradictory to the same information. This source of uncertainty can be reduced by soliciting multiple views of different experts.

- Contradiction: Availability of abundant and conflicting information.

- Multidisciplinary: Information that affects both several areas, causing understanding difficulties.

- Volatility: The propensity to variability of value over time.

- Measurement error or bad estimation: Measuring a quantity is always affected by the uncertainty due to the imprecision of the person taking the measurement or by the tolerance of the used instrument.

\subsection{Decision-maker uncertainties}

Decision-maker may be a person or a group. Each person reacts differently. The individual generators of uncertainty are not limited to his personality. Their experiences, knowledge and skills also play an important role (Baaziz, 2012). Individual generators are either psychological properties of the person, a lack of skills or low experience that creates uncertainty (AO2008, 2011):

- Doubt: State of mind which wonders in a kind of questioning.

- Hesitation: Lack of insurance and / or firmness.

- Skepticism: State of mind of a person brings 


\section{Opinion Section}

disbelief or distrust to opinions and received values.

- Irresolution: Personality trait of an incapable person to make decision whatever the context.

- Indecision: Mental state of a person who has difficulty with self-determination.

- Pessimism: State of mind of a person who persists to see only the bad side of things, to find everything is or will go wrong.

- Risk aversion: Excessive afraid of risk whose result is an excessive distrust that paralyzes decision. Thus, risk-taking is seen as a threat.

- Regretfully: Tendency to undermine the decision just taken by preferring an afterthought the not chosen option into the decision.

- Lack of self-confidence: Lack of assurance that one can have in one's own resources or destination.

Other individual factors such as perception, reasoning mode, preferences, beliefs, convictions and emotions can amplify uncertainty. But we distinguish them of the cited generators because they play a dual role as they are both able to increase or decrease uncertainty.

When the person is part of a group, it is in relation with the other members. Interactions and exchanges alter his behavior and give him/her more or less knowledge or doubt and impacting the position that results the uncertainty making (AO2008, 2011):

- Contradictory debates: The confrontation between divergent views.

- Influences of expertise: The influence of expert opinion.

- Subordinate relationship between persons: Influence of a hierarchical superior on the views of its collaborators (Baumard, 1997). This is common in the very hierarchical firms such as State-Owned Firms.

- Cultural differences: Existence of sub-groups with different visions of the firm's strategy.

- Group effects: Behavior pattern of a person related to the needs of the status and expectations of his group (Baumard, 1997). Often ideological or political affiliation is prioritized over the sense of belonging to the firm.

\section{Reduce the risk linked to the uncertainty of the competitive environment}

In fact, the environmental parameters generate signals that directly affect the firm and therefore the manager who picks up an environmental signal, reconstructs an image of this signal (with information's distortion) according to his/her own understanding (experiences, skills) and brings its own interpretation (behavioral psychology) and reacts to its own interpretation of the signal.

The explained uncertainties can guide the knowledge production process. Indeed, when they are explained, uncertainty is an impressive resource for decision-makers who are in a situation to reduce them without completely eliminate. There is probably a degree of uncertainty beyond which decision-makers becomes powerless and expose himself excessively to their management or their mandatory.

The main actions allowing to manage uncertainty in order to reduce its risks (AO2008, 2011) are:

- Correctly describe the unknown areas by establishing a new form of flexible organization, better prepared for unexpected events, enough resilient to adapt to uncertain environments.

- $\quad$ Further investigate some of the unknown but plausible phenomena before making irreversible choices. It comes to organize trials upstream of decisive choices and avoid incurring their downstream effects. For this, there should be implemented a Strategic Intelligence Information System (SIIS) able to maintain a permanent state of the environment scanning and monitoring to identify signals announcing unexpected effects (Baaziz \& Quoniam, 2013).

Find ways to make reversible choices that can interfere with the lesser known areas and provide the means to return to these choices, if there are unexpected effects.

\section{Of the Transformation to a new form of Organization to deal with uncertainty}

So dare to take the risk of transforming the organization towards models enabling enough proactivity, such as the "Extended Enterprise" model.

The major risk would be an inertia which is a kind of resistance to fast and radical changes resulting from the transformation (Keen, 1981). We identify several sources of inertia (Besson \& Rowe, 2011):

- Psychological inertia related to the preference of the status quo; 


\section{Opinion Section}

- Cognitive inertia related to patterns of interpretation of the actors, resulting from their past experiences;

- Socio- technical inertia related to the coherence and interdependence of technical systems between them of the one part, technical systems and skills to run them, on the other part;

- Political inertia related to the sharing of authority, the governance form and the alliances;

- Economic inertia related to the required investments and the existence of sunk costs.

For the firm, the political, socio-technical and economic aspects are crucial to overcome inertia and begin the process of transformation (Besson \& Rowe, 2011). Indeed, decision-makers must be willing to accept the declination and sharing power. This is a major policy decision sine qua non condition for initiating the process of transformation towards a new form of resilient organization.

The transformation process must inevitably pass through four distinct, gradual and scalable phases (Besson \& Rowe, 2011):

1. Phase of uprooting that allows them out of the old organization;

2. Phase exploration / construction of the new organization;

3. Phase stabilization / institutionalization of the new organization;

4. Phase optimization / routinization.

A strategy for driving the transformation helps to reduce risks and uncertainties associated with the phases of the process (Besson \& Rowe, 2011).

\section{Of the need to rebuild a Strategic Intelligence Information System to deal with uncertainty}

\subsection{Strategic Intelligence Information System}

In such competitive environment, it is necessary to provide a tool for management of resilient ownedstate firms, allowing the conception and monitoring the Strategies with an improved visibility for piloting their activities according to their abilities "intramural" and "extramural" considering the influence of signals sensed in the environment where they operate. Hence the need to implement an information system strategic intelligence, able to (Baaziz \& Quoniam, 2013):
- Federate their knowledge and critical skills;

- Ensure the rapprochement with firms that may have conjugated interests and complementary skills;

- Organize and prepare internal and external information for improved visibility and decision-making;

- Facilitate the exploitation of external knowledge bases such as patent databases in order to find practical alternatives of development coupled with a creative vision "out of the box" (Quoniam, 2013);

- Scan external environment to detect the favorable signals for its positioning;

- Facilitates decision making and reduce risks due to uncertainties inherent in its strategic choices.

The Strategic Intelligence Information System cannot create a synergy for decision-makers, only if it is able to create this synergy between the own knowledge and critical skills of the firm (Knowledge Management), the ability to decrypt signals and changes in the environment where the Firm operates (through a competitive intelligence system) in order to claim to relevant decisions in a timely manner (by using the decision support tools known as Business Intelligence).

Here, the concepts of Knowledge Management (KM), Competitive Intelligence (CI) and Business Intelligence (BI) operate at different levels of management: from strategic to operational (Baaziz, 2012).

\subsection{The empirical model of "synergy of the triptych"}

The decision cannot be relevant only if it is taken in a context of intelligent learning organization where both internal KM and external CI information are available, up to date, analyzed and contextualized enabling the synergy of the triptych: KM, CI and BI.

The decision support system (BI) can be based on the outcome of KM and CI in order to constitute hypotheses, analysis of alternatives for helping to lead the decision. The decision (outcome / output) becomes a component of organizational learning and enrich the knowledge base of the firm (based case study / input) (Baaziz, 2012).

We propose an empirical model of decision making, as follows: 


\section{Opinion Section}

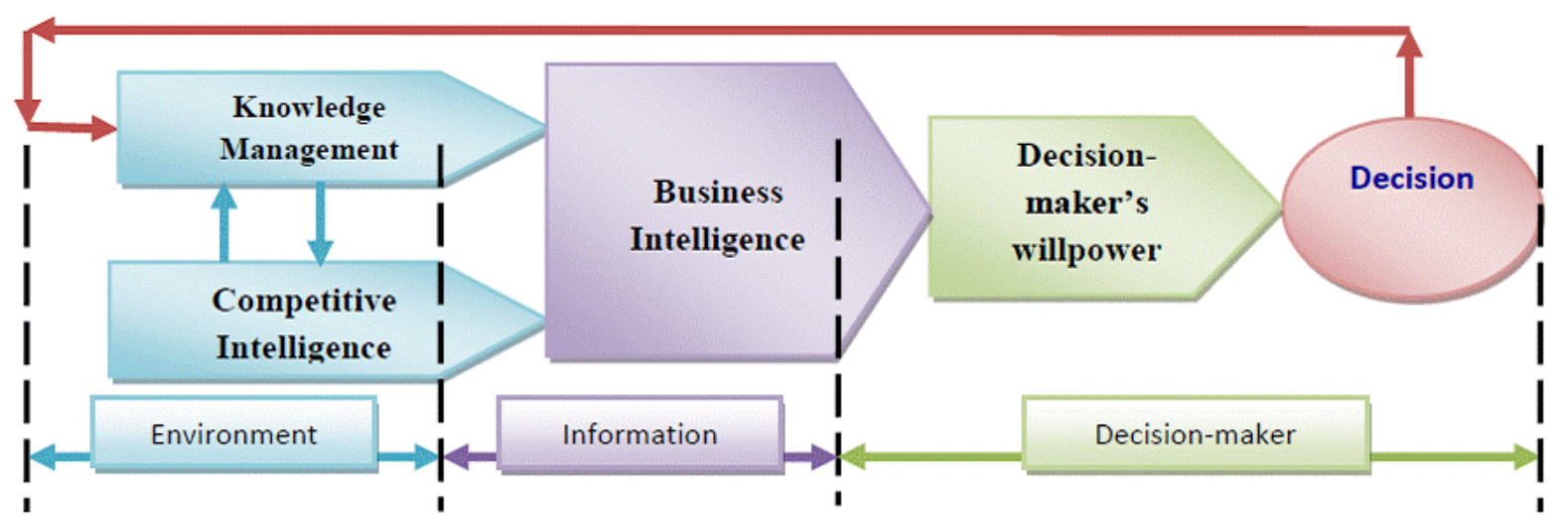

Fig. \#1. Diagram of the BI processes of the synergy with KM and CI

This process is apparently simple but in fact more complicated:

1. First, relative to the prerequisites for this process, with the following assumptions: An environment conducive to a learning organization where the asset "knowledge" should be the focus of managerial concerns (Pesqueux, 2004), in order to get a return on investment visible operated on intangible assets. A firm knowledge should be managed as a single focal point, control of knowledge and skills.

2. Then, there is the operation of other complex production processes of managerial knowledge: quest for information, interpretation and learning. We could say that with organizational knowledge, one is facing the production of organizational routines, hence the importance of the modification of routines to generate new knowledge. This transformation of knowledge obtained from external information that becomes an internal knowledge as a result of learning and ownership. (Pesqueux, 2005)

3. The third hypothesis is the "non-linearity" of this process due to the uncertainty listed, mainly the "Decision-maker" which is an integral part of this process (Baaziz, 2012). Indeed, it is obvious that with the same environmental deals, the same informational database and the same decision-making tools, it is unlikely that two people with different experiences can produce convergent decisions. Each person reacts differently. Its culture, experiences, knowledge and skills also play an important role (Baaziz, 2012). The individual generators are either psychological properties of the person, or a lack of skills or experience that creates uncertainty (AO2008, 2011). So, it is important to involve the human dimension, see psychological aspect of the decision-maker who constitutes the catalyst of the desired synergy.

4. The traceability of decisions' actions is granted by the Strategic Intelligence Information System (SIIS). Hence the possibility of reviewing the success factors or failures by checking the knowledge base describing the cases: subject, context, environment description, profiles of the decision-makers, taken decisions and actions, etc.

\subsection{Towards the integration of triptych KM, CI \& BI}

Customer satisfaction through Innovation, efficiency and performance of business processes requires upgrading the actors' skills, hence the need to use a KM system for the knowledge capitalization of the firm. Indeed, knowledge is a combination of information (or observations) and their interpretations by persons who, based on their beliefs, thought patterns, theories and personal or collective experiences, make sense of this information (Prax, 2000).

$\mathrm{KM}$ and $\mathrm{CI}$ are two activities that allow firms to be innovative, efficient and competitive by monitoring the one part, the external environment to decrypt weak signals, in order to go faster than its competitors and on the other, by following and monitoring internal changes they must operate in order to adapt, grow and innovate (Jakobiak, 2006; Goria, 2006). The goal of both is taking relevant decisions in a given context in order to grasp an opportunity or avoid a threat (Baaziz, 2012).

In front of the environmental and organizational constraints of enterprises and the strong similarity of used tools of competitive intelligence and knowledge management, we cannot practically be in one of the domains without practicing the other. 


\section{Opinion Section}

The strong similarities characterizing $\mathrm{KM}$ and $\mathrm{CI}$ tools lead us to combine efforts to set up for an improved synergy. We quote (Goria, 2006):

- Building networks and communities of practice,

- Guidance of the firm toward a learning organization,

- A logic-oriented innovation by building a sustainable competitive advantage,

- Strategic management of skills and human resources,

- Management of intangible assets (including those of its partners)

- Implication of the top management for the success of KM or CI project.

- Common IT infrastructure (servers, databases, web 2.0 , etc.)

In point of view of Information Technology, this similarity is extensible to decision support systems (BI) which link the results of the $\mathrm{KM}$ and $\mathrm{CI}$ domains in order to constitute the assumptions, analysis of situations to lead to better decisionmaking.

This is true if we consider that the CI as the “external” KM (Pesqueux, 2004), because:

- First, the tools, as well as terminology (web 2.0, mapping, search engine,

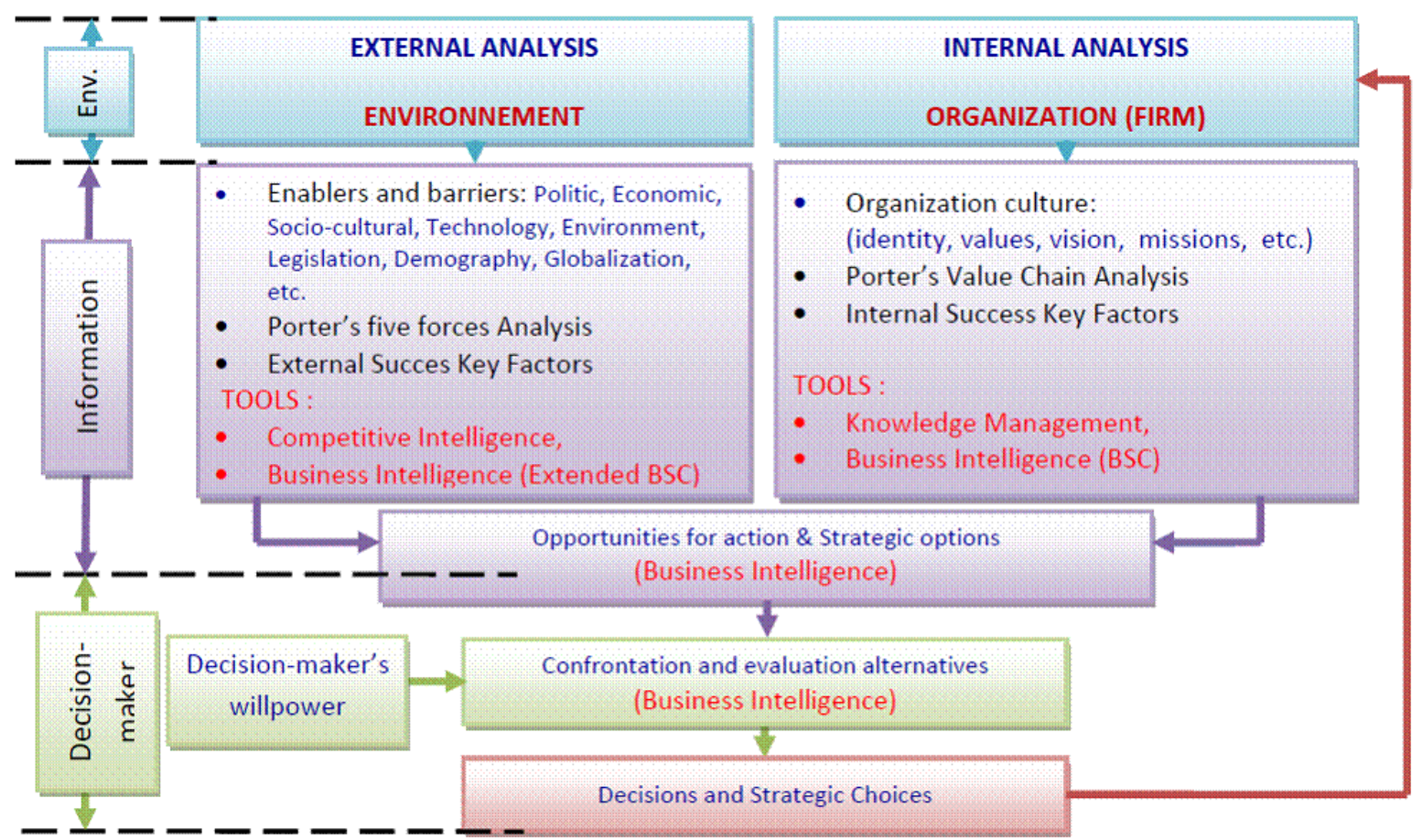

Fig.02. Enhanced LCAG model to Triptych Synergy model - describing the strategic review process information management tools, presentation, data warehousing, storage, statistics, correlation, data mining, big data, analytics, etc.) are reused in the context of KM, CI and BI;

- A good command of the internal knowledge management depends on the external knowledge, especially for the KM-oriented business skills and marketing (Pesqueux, 2004);

- The focus towards the client has greatly intensified in recent years. (Pesqueux, 2004).

This is a significant economic asset as investments in infrastructure; applications' platforms and a part of the study are common. Then just develop for each domain, its specificities.

The main contribution of this paper is the construction of the empirical model for the integration of the triptych KM, CI and BI to create synergies needed for suitable decision-making in an uncertain competitive environment and also enrich the strategic knowledge base for organizational learning.

This model is applicable to the overall strategic analysis as follows: 


\section{Opinion Section}

\section{Conclusion}

In conclusion, the Algerian State-Owned Firm must undergo deep changes at the organizational level by adopting a new form of organization resilient like "extended enterprise" in order to combine skills and resources to ensure a competitive advantage to local and foreign private firms whose "culture of networking and collaboration" is well anchored.

It must rebuild its information system accordingly, extended to its partners in order to exploit existing synergies "intramural" and "extramural". This gives the firm, the ability to innovate and reach the needed objectives of competitive advantage in an uncertain environment.

By using benchmarking tools and best practices with private and international firms operating in Algeria (like CEVITAL, HENKEL, SANOFIAVENTIS, etc..), the leaders among Algerian State-Owned Firms such as SONATRACH, SONELGAZ and their respective subsidiaries, can demonstrate the efficiency of their process in continuous improvement following the transformation of the firm and the extension of their information systems by:

- Better visibility of the political, economic, socio-cultural and technological environments in which they operate;

- Mapping knowledge and skills of the firm but also those of their partners contributing to its extended value chain;

- Mapping knowledge and skills of new key competitors in their main economic perimeter and / or geographical in order to achieve improved benchmarking;

- The easy identification of sensitive information "weak signals" and key skills for innovation, performance and competitive advantage;

- Creating favorable conditions for innovation by extending the partner network and building communities of practice;

- Anticipating customer requirements and alternative solutions to potential competitors.

\section{References}

Ansoff, H. I. (1975), "Managing Strategic Surprise by Response to Weak Signals", California Management Review, vol. XVIII no. 2, pp. 2133.

AO2008, (2011), Approches de l'incertitude et son impact sur la décision, Cahiers de la Sécurité Industrielle $\mathrm{N}^{\circ}$ 2011-06, Fondation pour une Culture de Sécurité Industrielle, Toulouse,
France.

Available:

http://www.FonCSI.org/fr/cahiers/

Armacosta, R. L., Pet-Edwards, J. (1999), Integrative risk and uncertainty analysis for complex public sector operational systems. Socio-Economic Planning Sciences, Volume 33, Issue 2, June 1999

Baaziz A., Quoniam L. (2013), Réduire les risques des décisions stratégiques dans les nouveaux environnements concurrentiels incertains : Cas des Entreprises Publiques Algériennes, Journée Scientifiques et Techniques de Sonatrach (JST'9), Centre des Conventions d'Oran, Algérie, 08 avril 2013

Baaziz A. (2012), Synergie du triptyque : Knowledge Management, Intelligence Economique \& Business Intelligence, Colloque International : Management et Performances : quelles spécificités et quelles pratiques?, ENCGT, Tanger - Maroc, Juin 2012

Baaziz A. (2006), Apport du Knowledge Management dans l'amélioration de la prise de décision dans une Organisation, 5ème Inforum, Oran, Avril 2006

Baaziz A., (2004), Mémoire de DU 3ème Cycle, Réflexion sur l'amélioration des performances des Ressources Humaines en tenant compte de l'exigence Qualité, Université de Perpignan (France), Septembre 2004

Baird, I.S., Thomas, H. (1985), Toward a contingency model of strategic risk taking. Academy of Management Review, 1O(2): 230243.

Baumard P. (1997), L'information stratégique dans la grande organisation, Systèmes d'Information \& Management, Vol. 2, No 2 (1997)

Besson P., Rowe F. (2011), Perspectives sur le phénomène de la transformation organisationnelle, Systèmes d'Information \& Management, Vol. 16, No 1 (2011)

Blondel F. Edouard S., El Mabrouki M. N. (2006), «Quelle articulation entre intelligence économique et knowledge management au sein de l'entreprise ? », XVème Conférence Internationale de Management Stratégique, Annecy / Genève 13-16 Juin 2006

Bouchon-Meunier, B. (1990), La logique floue et ses applications, Edition Addison-Wesley

Bretonès D., Said A. (2006), Intelligence économique (I.E) et Management des connaissances (K.M) : deux facettes complémentaires d'une même problématique, 


\section{Opinion Section}

Colloque «En route vers Lisbonne » -9 et 10 novembre 2006

Bright J. R. (1970), "Evaluating signals of technological change", Harvard Business Review, January/ February, p. 62-70

Couture A. (2000), Knowledge management et intelligence économique, Thèse, 2000

Cook, C., Cook, M. (2000), The Convergence of Knowledge Management and Business Intelligence, Auerbach Publications, New York, NY,

Daft R. L., Weick K. E., (1984), Toward a Model of Organizations as an Interpretation Systems, The Academy of Management Review, Vol. 9, No. 2 (Apr., 1984)

Ducreux J. M., Abate R., \& Kachaner N., (2009), "Le Grand Livre de la Stratégie",1ère édition, France: Edition d'Organisation, EYROLLES.

Fernandez A. (2008), Les nouveaux tableaux de bord des managers - Le projet décisionnel dans sa totalité, Edition d'Organisation

Goria S. (2006), Knowledge Management \& Intelligence Economique: Deux notions aux passés proches et aux futurs complémentaires, Journal en ligne ISDM N`27, Université du Sud Toulon Var, 4ème trimestre 2006

Hameed, I. (2004), Knowledge management and business intelligence: what is the difference?, available at: http://onlinebusiness.about.com/

Holopainen, M., \& Toivonen, M. (2012), "Weak signals: Ansoff today”, Futures, 44(3), 198205. doi:10.1016/j.futures.2011.10.002

Jakobiak F. (2006), L'Intelligence Economique, Edition d'Organisation.

Kaplan R. S., Norton D. P. (1992), The Balanced Scorecard - Measures That Drive Performance, Harvard Business Review, January-February 1992

Keen, P. (1981), "Information systems and organizational change", Communications of the ACM, Vol. 24, n 1 .

Knight F. H. (1921), Risk, Uncertainty \& Profit, Chicago University Press, Chicago, 1921.

Liebowitz J. (2006), Strategic Intelligence, CRC Press, Auerbach Publications

MacCrimmon K. R., Wehrung D. A. (1986), Taking Risks: The Management of Uncertainty. New York: Free Press.

March J. G., (1991), Exploration and exploitation in organizational learning. Organization Science Vol. 2, No. 1, February 1991
March J. G., Shapira Z. (1987), Managerial perspectives on risk and risk taking. Management Science, 33, 1404-1418.

Pablo A.L., Sitkin S.B., Jemison D.B. (1996), Acquisition Decision-Making Processes: The Central Role of Risk, Journal of Management October 1996vol. 22 no. 5723 746, doi: 10.1177/014920639602200503

Pesqueux Y. (2006), A critic of Knowledge Management, article publié avec M. Ferrary en 2006 dans Economica

Pesqueux Y. (2005), Management de la Connaissance: Un modèle organisationnel ?, article publié sur le site HAL du CNRS, 2005.

Pesqueux Y. (2004), Apprentissage organisationnel, économie de la connaissance : mode ou modèle ?, Cahiers du LIPSOR, Série Recherche ${ }^{\circ} 6$, Septembre 2004

Pfeffer, J., Salancik, G.R. (1978), The external control of organizations. New York: Harper \& Row.

Porter M. E. (1985), Competitive Advantage, MCM, 1985

Prax J.Y. (2000), Le guide du knowledge management, concepts et pratiques du management de la connaissance, Dunod, 2000.

Quoniam L. (2013), Brevets comme outil d'innovation, de créativité et de transfert technologique dans les pays en voie de développement, Journée Scientifiques et Techniques de Sonatrach (JST'9), Centre des Conventions d'Oran, Algérie, 08 avril 2013

Riabacke A. (2006), "Managerial Decision Making Under Risk and Uncertainty." IAENG International Journal of Computer Science 32, no. 4 (2006): 453-459.

Rossel, P. (2012), "Early detection, warnings, weak signals and seeds of change: A turbulent domain of futures studies", Futures, 44(3), 229239. doi:10.1016/j.futures.2011.10.005

Shapira Z. (1995), Risk taking: a managerial perspective, Russell Sage Foundation, New York.

Sun Tzu (2005), "L'art de la guerre - Les treize articles" (édition électronique.), France: Ebooks libres et gratuits.

Sutcliffe K. M., Christianson M. K. (2011), Managing the Unexpected, Center for Positive Organizational Scholarship (POS), available on : http://www.centerforpos.org

Thiry M. (2002), Combining value and project management into an effective programme 


\section{Opinion Section}

management model. International Journal of Project Management, Volume 20, Issue 3, April 2002

Wehrung, D.A.. Lee, K.H., Tse, D.K., Vettinsky, LB. (1989), Adjusting risky situations: A theoretical framework and empirical test. Journal of Risk and Uncertainty, 2: 189-212.

Weick, K. E. et Sutcliffe, K. M. (2007), Managing the Unexpected: resilient performance in an age of uncertainty. Wiley, Jossey-Bass, San Francisco.

Weick, K. E. (2009), Making Sense of the Organization: The Impermanent Organization. Southgate Chichester, UK: John Wiley \& Sons.
Zimmermann, H. J. (2000), An application-oriented view of modeling uncertainty. European Journal of operational research, Volume 122, Issue 2, 16 April 2000

Zio et Pedroni (2012), Uncertainty characterization in risk analysis for decision-making practice, Cahiers de la Sécurité Industrielle N 2012-07, Fondation pour une Culture de Sécurité Industrielle, Toulouse, France. Available: http://www.FonCSI.org/fr/cahiers/ 